\title{
Level of Soft Skill in the Implementation of Work- Based Learning among Community College Students
}

\author{
Azita Binti Ali (Ph.D) ${ }^{1}$, Shuhada Mahmod $^{1}$ \\ 1 Universiti Tun Hussein Onn Malaysia
}

\begin{abstract}
The issue of graduate unemployment often crops up in the mass media; and more often than not, the discussions have centred on the failure of tertiary educational institutions to churn out quality graduates. Thus, the method of workbased learning (WBL) is seen as a way to improve the soft skills of the graduates. The study was conducted using quantitative research survey; the design of the study used an adapted questionnaire as an instrument. Data were analysed using Statistical Package of Social Science (SPSS) version 20. The respondents consisted of 97 students who attended WBL programmes at a community college. Descriptive statistics was used to extract data from the questionnaires for the calculation of mean. The findings reveal that the level of soft skills among community college students was high, and they include these abilities: communication skills, problemsolving skills, learning and information management, professional ethics skills and leadership skills.
\end{abstract}

\section{Introduction}

According to Community College Management Sector GCMS (2010), workbased learning (WBL) is an approach to learning and innovative teaching that involves cooperation between Community College Management Sector and the participating companies. WBL is a learning approach that requires work placements as part of the students' learning process in their institutions; this learning style will increase employmentrelated competencies, real-world work experiences and expertise in industrial applications (Becker, 2013). This may address the issues related to graduate unemployment-often talked about by the academic community and the employers who regard it as a failure of higher educational institutions to produce quality graduates. Students with soft skills could compete in the job market or work places, and they are ready to tackle the challenges of globalisation today (Anuar \& Esa (2010); it is evident from various findings that WBL as one of the effective ways to improve the soft skills ommunity college students.

The collaboration between the industry and educational institutions is a major milestone towards the consolidation of higher education. According to Hassan (2007), the cooperation between educational institutions and the industry is not well coordinated and implemented; the former have the duty to include compulsory industrial trainings for the students in the curriculum, and the latter has the responsibility of providing the required training to the students. The cooperation between the educational institutions and the industry is the best way to shape the curriculum in determining the skills required. 
Graduate unemployment in Malaysia has become a worrying phenomenon in recent years. This problem occurs not only in Malaysia but also in many other developing countries like the Philippines, Indonesia, India and even in developed countries such as Britain and the United States (Stevens,2014). Employers want employees who have technical or hard skills and soft skills. The employers of any company today are looking for graduates who have a combination of technical and soft skills, graduates in Malaysia have sufficient technical skills, but employers are less satisfied with their soft skills.

Employers and the industry in Malaysia have a limited number of graduates to choose from; many have the knowledge and technical skills, but most of them are not able to communicate properly (Zaharim, 2009). Hassan (2007) states that although the university has put in place various measures to ramp up the quality of teaching and learning, the students still do not have the teamwork skills and experience required by the employers. Syed (2013), states that entrepreneurship is the key transformation factor that can solve the unemployment problem nowadays.

Professional ethics and morals are increasingly taking a prominent role due to the frequent occurrences of white-collar crimes; these are very serious matters and they involve the students (Shahrul Anuar Mohamed, 2011). Leadership skills are important elements in the formation of the nation's cultural identity, but the students are not paying much attention in developing these necessary skills (Esa, 2013).

\section{Literature Review}

\subsection{Communication Skills}

According to Zaharim (2009), the employers are satisfied with the technical skills of graduates but are not very happy with their communication skills, which is still at a low level. This statement is supported by Pumphery (2001) which states that a large number of graduates do not have the skills required by the employers. Students will benefit from the implementation of the workbased learning (WBL); their communication skills will improve and indirectly WBL prepares the students to meet the requirements of the industry. This is because students who have undergone WBL have actual experience and are accustomed to working conditions in the industry.

\subsection{Critical Skills and Problem-Solving Skills}

Critical and problem-solving skills are some of the abilities the tertiary students should acquire as outlined by the Malaysian Higher Education Institutions. Problem solving requires a student to think critically, creatively, innovatively, and analytically; and at the same time, he or she must be capable of applying the knowledge and understanding to new and different problems (Acar \& Newman, 2003).

\subsection{Teamwork Skills}

Teamwork skills, also known as teamwork or group work, are soft skills that can be applied through the implementation of work-based learning (WBL). Hambur, Rowe and Luc (2002) define teamwork skills as a structured collection of individuals who interact with one another to achieve common goals. According to Anderson (2007), teamwork skills are a necessary ingredient for graduates to compete for and complete future work. Work-based learning is an effective approach that can train graduates to have the required teamwork skills for future tasks.

\subsection{Learning Skills and Information Management}

In this $21 \mathrm{st}$ century, the international community is more concerned with increasing knowledge through the concept of continuous learning and information management. Learning skills and information management are processes of democratising education, which include programme acquisition of knowledge, skills and competences, formal or 
informal experiences, and training in the workplace. Global competitiveness and diversity requirements compel people to constantly update their knowledge and skills. The implementation of work-based learning (WBL) can help improve the soft skills of students through continuous learning and information management, thereby producing all-round employees the employers expect.

\subsection{Entrepreneurial skills}

According to Harun, (2010), entrepreneurial skills are some of the soft skills which students need to master while they are in their earlier years of schooling or later years of higher education. With entrepreneurial skills, a person has the ability to explore opportunities and develop an awareness of risk, creativeness and innovativeness in business and workrelated activities, (Kementerian Pengajian Tinggi , 2006). The statement is supported by Kuratko and Hodgetts (2007), that students require entrepreneurial skills so that they can be shrewd entrepreneurs who are capable of looking for opportunities, taking risks and translating dreams and ideas into reality.

\subsection{Professional Ethics and Moral Skills}

According to the Kementerian Pengajian Tinggi Malaysia (2006), successful professional practices and fruitful social interactions demand the observance of professional and high moral standards. The Kementerian Pengajian Tinggi Malaysia (2006) highlights three stages in the development of professional ethics moral skills: the ability to understand the impact of economic, environmental and socio-cultural factors on professional practices; the ability to analyse problems related to ethics and make decisions in solving them; and ability to practise ethical behaviours, in addition to having a sense of responsibility to the society.

\subsection{Leadership Skills}

The employers expect their employees to possess leadership skills. According to the
Kementerian Pengajian Tinggi Malaysia (2006), leadership skills involve the ability to practise leadership in a variety of activities through four levels of knowledge about the basic theory of leadership: the ability to lead projects, the ability to understand and interchange roles between the team leader and team members, and the ability to supervise the team members. Students can develop leadership skills by going through work-based learning (WBL).

\section{Methodology}

Descriptive and inferential surveys were conducted to collect quantitative information. For this study, the population is composed of diploma students of Selayang Community College, Community College Ampang, Community College Segamat 2, Community College Hulu Langat, and Community College Kota Melaka, all of which had carried out the implementation of the work-based learning (WBL). This study used the random sampling technique and the respondents were the students of community colleges in Malaysia. The population in this study consists of 104 people and the selected sample is 97 .

\subsection{Instrument}

The instrument used in this study was the distribution of questionnaires. The questionnaire consists of two parts. Part A includes questions related to the backgrounds of the respondents. Part B aims to identify the level of soft skills of community colleges when implementing WBL.

\subsection{Result}

This section contains the descriptive analysis for each item of soft skills and its level for respondents undergoing WBL. The overall average mean score for the level of communication skills is (4.1218), which indicates a high level. Overall, the level of soft skills among community colleges which had implemented WBL is high. Table 4.1 below 
shows the mean score for each soft skill among the community colleges.

Table 4.1: Mean Score for Soft Skills

\begin{tabular}{|l|c|c|}
\hline $\begin{array}{l}\text { Overall Average Mean } \\
\text { Score of Communication } \\
\text { Skills }\end{array}$ & 4.1218 & High \\
\hline $\begin{array}{l}\text { Overall Average Mean } \\
\text { Score of Critical skills and } \\
\text { Problem-Solving Skills }\end{array}$ & 4.0946 & High \\
\hline $\begin{array}{l}\text { Overall Average Mean } \\
\text { Score of Teamwork Skills }\end{array}$ & 4.2297 & High \\
\hline $\begin{array}{l}\text { Overall Average Mean } \\
\text { Score of Continuous }\end{array}$ & 4.1219 & High \\
$\begin{array}{l}\text { Learning and Information } \\
\text { Management }\end{array}$ & & \\
\hline $\begin{array}{l}\text { Overall Average Mean } \\
\text { Score of Entrepreneurship } \\
\text { Skills }\end{array}$ & 4.0240 & High \\
\hline $\begin{array}{l}\text { Overall Average Mean } \\
\text { Score of Professional Ethics } \\
\text { and Moral }\end{array}$ & 3.9410 & High \\
\hline $\begin{array}{l}\text { Overall Average Mean } \\
\text { Score of Leadership Skills }\end{array}$ & 4.2104 & High \\
\hline
\end{tabular}

\section{Findings and Discussions}

\section{The Levels of Soft Skills}

The overall findings derived from data analysis show that students who took WBL programmes in the community colleges obtained high mean score for the communication skills. The highest mean score goes to communication skills in English as well. High mean scores are recorded for both critical skills and problem-solving skills. These skills are helpful for students when they are working in the real-world organisations in the near future. This finding contradicts the study of Anderson (2007), which states that all people use critical thinking while solving problems because they lack self-awareness and other features that enable them to interpret and evaluate the problem. Most previous studies show the same trend that students do are not use critical thinking to analyse problems properly. However, the researcher found that most community college students have good critical thinking skills and problem-solving skills.

The analysis of data shows a high score for teamwork skills. This is because when community college students take up industrial training, they develop teamwork skills in order to cooperate with other workers in the companies they are attached to. This proves that WBL is able to improve students' teamwork skills. In fact, students can also cooperate with members of the group in sharing ideas, knowledge and ways of improvement (Rosenshine, 1999).

The results also show that there are high scores for continuous learning and information management among community college students. The finding shows that students who pursue tertiary education have the aim of seeking knowledge, and they are rewarded with what they desire. This is because community college students are open-minded; they are ready to assimilate new ideas or anything that brings positive results.

Other than that, the results also show a high score for entrepreneurial skills; community college students are good at identifying business opportunities. These findings are in line with the studies carried out by Stevens, B. (2014); graduates can identify business opportunities that endeavour to solve the problem of unemployment. This shows that community college students trained under the WBL approach have good entrepreneurial skills to tackle the problem of unemployment today. This study finding is supported by Mitchelmore and Rowley (2010), who says that graduates must think of themselves as an inventor rather than a job seeker.

In the course of investigation in meeting the objectives of this study, the respondents were asked seven questions. The results show that the score for professional ethics and moral is high. As we know, there are lots of immoral or unethical activities happening among students. This problem will adversely affect the process of building up a pool of first-class human capital, which is vital to the future success of the country. However, the community college students have proven that they possess a high level of professional ethics and moral . a Characterised by good attitudes 
and work ethics, community college students will always behave and conduct business deals with the utmost propriety, wherever they are. The findings state that the community college students can practise ethical behaviours; this is consistent with a study conducted by Zaharim (2009), which reveals that quality employees are not only experts in their work, but they have an admirable character and behaviour.

Based on the results of data analysis, there is a high level of leadership skills among community college students. These findings are supported by the study of Lee Barron (2012), which states that when a person has good leadership skills, he or she can influence and convince people inside and outside organisations to work and help to achieve organisational goals. Based on the findings of this study, the community college students have excellent leadership skills; they can mingle with and judge people well. The implementation of WBL at community colleges is certainly a wise move, which will produce students armed with good leadership skills.

\section{Conclusions}

Premised on the discussions of the findings, it is concluded that the implementation of WBL programmes in the community colleges has produced students with a high level of soft skills. The findings clearly show that students who have attended community colleges that implemented WBL possess a high level of soft skills. The first question of the study is answered: the community college students have a high level of communication skills, particularly those who speak in languages other than English. This is because most of the students who attend WBL are Malay. The findings also show that the community college students have a poor command of English. The second research question is answered: the community college students have a high level of critical skills and problem-solving skills. This is because students who have attended WBL are exposed to higher-order thinking skills required by the employers. The implementation of WBL at community colleges is effective in training thinking students. In addition, teamwork skills are required in the implementation of the WBL at community colleges. Students can organise group activities together, to acquire and exchange views and ideas. Community college students are also very open-minded, and receptive to the idea that they will benefit from interacting with others. Overall, the community college students have a high level of soft skills. This is in line with the requirements of the Ministry of Higher Education for tertiary institutions to produce students who have strong soft skills. This indicates Community Colleges are successfully implemented WBL to produce students who meet the requirements of the industry

\section{References}

1. Acar, B.S and Newman, I.A.(2003). Students as Tutors-Learning Problemsolving Skills by tutoring PBL. International Journal Engineering Education, Vol, 19, No.5, 712-716.

2. Anuar, A, \& Esa, A (2010). "Penerapan Kemahiran Insaniah di Pusat Giat MARA (PGM): Satu Analisis ATIKAN: Jurnal Kajian Pendidikan, 3(2) Desember 2013 149 Perbandingan" dalam Esa, A \& Mustafa, M.Z. Kemahiran Insaniah: Kajian di Institusi-institusiPengajian. BatuPahat, Johor: Penerbit UTHM [UniversitiTun Hussein Onn Malaysia], ms.1-19.

3. Anderson, K. M. (2007). Differentiating instruction to include all students prventing school failure. International Journal Engineering Education. Vol 51, Iss 3: .49-54.

4. Becker, G. (2013). Development Education and OtherAcademic Programs. Human Capital, 1-10.

5. Hambur, S., Rowe, K., \& Luc, L. T. (2002). Graduate skills assessment. Australian Council For Educational Research. Commonwealth Department of Education Science \& Training.

6. Harun, N. (2010). Aspirasi Kerjaya Keusahawanan Dalam Kalangan institusi 
Pengajian Awam.Jurnal Pendidikan Malaysia, 11-17.

7. Hassan, A. (2007). Isu dan Strategi ke Arah Pembangunan Modal Insan Sektor Pengajian Tinggi Bertaraf Dunia.Pengurusan Awam, 23-44.

8. Hurley (2008).The Importance of Strong Business Communication Skills. McGraw Hill Inc.

9. Othman,H .(2009.). Pelaksanaan Pendekatan Pembelajaran Berasaskan Pengalaman (PBL dan POBBL) bagi Meningkatkan Kemahiran Insaniah Pelajar. Pemikiran Kritis dan Kemahiran Menyelesaikan Masalah.

10. Kaprawi, N. (2010). Kajian Tinjauan Secara Kuantitatif. dlm. NorainiI dris (Pnyt). Penyelidikan dalam Pendidikan, 195-214. Kuala Lumpur. Mc. Graw-Hill (M) Sdn. Bhd.

11. Kementerian PengajianTinggi Malaysia (2006).Modul pembangunan kemahiran insaniah (soft skills) untuk Instutusi Pengajian Tinggi Malaysia.Serdang: Penerbit Universiti Putra Malaysia.

12. Krejcie, R.V, Morgan, D.W. (1970) Education and Psychological Measurement: Determining Sample Size for Research Activities.

13. Kuratko, F., \& Hodgetts, M. (2007). Entrepreneurship: Theory, process and practice. Taunton, MA. Thomson \& South-Western

14. Lee Barron, J. R. (2012). Martial Arts Training as a Method of Modifying Attitudes and Behaviors in TheClasroom. International Journal of Combat Martial Arts and Sciences ICMAUA.11 (I), ms. 17-22.

15. Mitchelmore, S.\& Rowley, J. (2010). Entrepreneurial competencies: a literature review and development agenda. International Journal of Entrepreneurial Behavior \& Research, 16(2), 92 -111.

16. Mohd Najib Ghafar. (1997). Pembinaan dan Analisis Ujian Bilik Darjah. Skudai: Universiti Teknologi Malaysia (UTM).

17. Pumphery, J.(2001). A Comprehensive Summary of Generic SKilss Requirement. Paper Research The Council for Administration London.
18. Rosenshine, B.V. (1999). Effective Teaching In Industrial Education And Training. Journal Of Industrial Teacher Education. Vol, 23(2): 5-19.

19. Shahrul Anuar Mohamed, A. A. (2011). Pembangunan Etika dan Moral Dalam Kursus kursus yang Ditawarkan di Universiti Teknikal Malaysia Melaka (UTeM). Journal of Human Capital Development, 141-155.

20. Stevens, B. (2014). Career and Technical Education Work- Based Learning Guide.Richmon, Virgnia: Education, Virginia of Department.

21. Syed, Z.A. (2013). The need for inclusion of entrepreneurship education in Malaysia lower and higher learning institutions.Education + Training. Vol. 55 No. 2, pp. 191-203.

22. Zaharim, A.(2009). Employers "Perceptions and expectstions toward engineering Graduates: A study case. Proceedings of the $6^{\text {th }}$ WSEAS International Conference on Engineering Education, Rodos Greece, July 22-24. ISSN: 1790-2796. ISBN: 978-960-474100-7.23-29 